Article

\title{
Determination of Posaconazole in Plasma/Serum by High-Performance Liquid Chromatography with Fluorescence Detection
}

\author{
Peter H. Tang \\ Departments of Pediatrics, Pathology and Laboratory Medicine, Cincinnati Children's Hospital Medical Center, \\ University of Cincinnati College of Medicine, 3333 Burnet Avenue, Cincinnati, OH 45229-3039, USA; \\ peter.tang@cchmc.org; Tel.: +1-(513)-636-7328; Fax: +1-(513)-636-8850 \\ Academic Editor: Fabio Gosetti \\ Received: 13 February 2017; Accepted: 3 May 2017; Published: 8 May 2017
}

\begin{abstract}
A sensitive high-performance liquid chromatographic (HPLC) method is described for the determination of posaconazole in human plasma/serum. The method is based on a single dilution step by treating the sample with methanol, and followed by the direct injection of the sample into the HPLC system. Posaconazole and internal standard ketoconazole in the methanol extract are subsequently analyzed by using a fluorescence (FL) detector at optimized wavelengths (excitation $245 \mathrm{~nm}$ and emission $380 \mathrm{~nm}$ ). The method achieves a linear detector response for peak height measurements over the concentration range of $0.1-10 \mu \mathrm{g} / \mathrm{mL}$ which adequately covers the therapeutic range for appropriate patient monitoring. The chromatographic time is less than $8 \mathrm{~min}$ per injection, an improvement over most published HPLC/FL or HPLC/UV methods. The method's limit of quantitation, linearity, imprecision, and accuracy met all criteria required by the Guidance for Industry Bioanalytical Method Validation. In comparison to other published methods, the current method would be of interest to analytical and clinical laboratories because it employs simple, rapid, and cost-effective procedures.
\end{abstract}

Keywords: posaconazole; ketoconazole; HPLC; fluorescence

\section{Introduction}

Posaconazole is a triazole antifungal drug with enhanced activity against major microorganisms, including the Candida, Aspergillus, and Zygomycetes fungal groups [1-4]. It is approved for antifungal prophylaxis of invasive Candida and Aspergillus infections in patients who are immunocompromised, such as those with hematologic malignancies with prolonged neutropenia from chemotherapy, or hematopoietic stem cell transplantation recipients with graft versus host disease. Posaconazole is believed to inhibit lanosterol $14 \alpha$-demethylase, an enzyme responsible for the conversion of lanosterol to ergosterol, which is an essential component of the fungal cell membrane [5]. This inhibition results in depleting ergosterol and accumulating toxic methylated sterol precursors within the fungal cell membrane, and thus weakening the structure and function of the cell membrane and leading to fungal cell death.

For treating patients in various conditions, posaconazole is formulated into three forms including an oral suspension, a delayed-release tablet and an intravenous formulation which can be readily dictated by the clinicians. The pharmacokinetics and pharmacodynamics of each formulation have been outlined extensively [6-11]. The oral formulations have exhibited significant inter-patient and intra-patient variations in bioavailability due to inconsistent absorption, metabolism, elimination, or drug-drug interactions. The intravenous formulation is suitable for patients who cannot tolerate oral formulation, however, its solubilizing excipient may cause additional renal toxicity for patients 
with renal impairment [12]. Posaconazole could accumulate in tissues due to its hydrophobic nature; as such, its disposition could perhaps augment its efficacy. To successfully manage invasive fungal infections, the clinician strives for antifungal therapeutic drug monitoring. Therapeutic drug monitoring of a patient's serum or plasma has been a useful tool to detect drug exposures outside of the therapeutic window and to help individualize a dosage regimen and treatment, increasing therapeutic efficacy, and decreasing side effects [13-35]. Reported methods for the analysis of posaconazole are mostly high-performance liquid chromatography (HPLC) with mass spectrometry [13-25], ultraviolet [26-31] and fluorescence [32-35] detections. Mass spectrometry (MS) and tandem mass spectrometry (MS/MS) are superior in sensitivity and specificity to ultraviolet (UV) and fluorescence (FL) detections. However, the purchase and operating costs of LC-MS and LC-MS/MS are high. Therefore, the need for the therapeutic drug monitoring of posaconazole in pediatric samples with a simple, rapid, and cost-effective procedure prompted the development of the current method.

\section{Materials and Methods}

\subsection{Chemicals and Reagents}

Posaconazole, ketoconazole, trifluoroacetic acid (TFA) and ammonium acetate were obtained from Sigma-Aldrich (St. Louis, MO, USA). HPLC-grade organic solvents were purchased from Fisher Scientific (Fair Lawn, NJ, USA) and used without further purification. Lyphochek ${ }^{\circledR}$ Therapeutic Drug Monitoring Control was from Bio-Rad (Hercules, CA, USA).

\subsection{Instrumentation and Chromatographic Conditions}

The Hitachi Chromaster ${ }^{\mathrm{TM}}$ HPLC system was equipped with a Model 5110 quaternary pump, Model 5210 autosampler, Model 5310 column oven, and Model 5440 FL detector. The output signal was monitored and processed using the EZChrom Elite ${ }^{\circledR}$ software. The analytical column was a $250-\mathrm{mm} \times$ 4.6-mm ODS HYPERSIL column (Thermo Scientific) with 5- $\mu \mathrm{m}$ spherical particles equipped with a Phenomenex Security Guard (C18 cartridge, $4 \times 3-\mathrm{mm}$ ). Details of chromatographic and detection conditions are described in Table 1. The mobile phase was filtered through a 0.2- $\mu \mathrm{m}$ MAGNA nylon filter (GE Water \& Process Technologies, Minnetonka, MN, USA) under reduced pressure.

Table 1. HPLC conditions.

\begin{tabular}{cc}
\hline Parameters & Conditions \\
\hline Column & ODS HYPERSIL, $5-\mu \mathrm{m}, 250 \times 4.6 \mathrm{~mm}$ \\
Mobile phase & Ammonium acetate $(0.1 \mathrm{M}):$ water:acetonitrile:TFA $(409 / 590 / 1, v / v / v)$ \\
Mode & Isocratic elution \\
Oven & $45^{\circ} \mathrm{C}$ \\
Autosampler & $5{ }^{\circ} \mathrm{C}$ \\
Flow rate & $1.1 \mathrm{~mL} / \mathrm{min}$ \\
Injection & $10 \mu \mathrm{L}$ \\
Detector settings & $245 \mathrm{~nm}(\mathrm{Ex})$ and $380 \mathrm{~nm}(\mathrm{Em})$ \\
Run time & $7 \mathrm{~min}$ \\
\hline
\end{tabular}

\subsection{Preparation of Calibrator and Quality Control Samples}

Individual stock solutions of posaconazole $(100 \mu \mathrm{g} / \mathrm{mL})$ and ketoconazole $(100 \mu \mathrm{g} / \mathrm{mL})$ were prepared in methanol. The stock solution of posaconazole was diluted with analyte-free pooled human serum (blank sample) to prepare calibrator samples over the range of $0.1-10 \mu \mathrm{g} / \mathrm{mL}$. Quality control (QC) samples were similarly prepared containing $0.3,2,4$, and $8 \mu \mathrm{g} / \mathrm{mL}$. Portions of calibrator and QC samples were stored in 1.5-mL polypropylene screw-top tubes. Internal standard (IS) ketoconazole solution $(2 \mu \mathrm{g} / \mathrm{mL})$ was prepared in methanol from the stock solution $(100 \mu \mathrm{g} / \mathrm{mL})$. All solutions and samples were stored at $-20^{\circ} \mathrm{C}$ until required. 


\subsection{Sample Preparation Procedure}

A single dilution step was employed for sample preparation in order to avoid the time-consuming extraction procedure such as solid-phase extraction, filtration, evaporation and reconstitution. Because organic solvent could extract posaconazole from the sample matrix and precipitate proteins, several organic solvents including acetonitrile, methanol, and mixtures of acetonitrile-methanol $(3 / 1,2 / 2$, and $1 / 3, v / v)$ were examined. After protein precipitation and centrifugation, a clear supernatant was obtained without further manipulation.

A patient's serum, calibrator, or QC sample $(100 \mu \mathrm{L})$ was pipetted to a microcentrifuge tube, followed by internal standard solution $(100 \mu \mathrm{L})$ and methanol or other organic solvents $(300 \mu \mathrm{L})$. After vortex-mixing for $1 \mathrm{~min}$, the mixture was centrifuged at $4{ }^{\circ} \mathrm{C}$ for $10 \mathrm{~min}$ at $10,000 \mathrm{rpm}$. After protein precipitation, the supernatant was transferred to an autosampler vial for analysis. A $10-\mu \mathrm{L}$ aliquot of supernatant was injected onto the HPLC system.

\subsection{Method Validation}

\subsubsection{Selectivity}

To explore possible sources of interference, several lyophilized products from human blood containing endogenous components, metabolites, decomposition products, concomitant medication and other exogenous xenobiotics (included in the Lyphochek ${ }^{\circledR}$ Therapeutic Drug Monitoring Control) were examined. These substances included acetaminophen, amikacin, amiodarone, amitriptyline, caffeine, carbamazepine, chloramphenicol, cortisol, cyclosporine, desipramine, digoxin, disopyramide, estriol, ethosuximide, flecainide, gentamicin, haloperidol, imipramine, lidocaine, lithium, methotrexate, $\mathrm{N}$-acetylprocainamide, netilmicin, nortriptyline, phenobarbital, phenytoin, primidone, procainamide, propranolol, quinidine, salicylate, T3, T4, theophylline, tobramycin, tricyclic antidepressants, thyroid-stimulating hormone (TSH), valproic acid, and vancomycin. These lyophilized products were treated as patient samples and processed in an identical fashion, as described in the sample preparation procedure section. Analyses of patients' samples $(n=10)$ were also carried out, which were previously tested for felbamate, lacosamide, lamotrigine, methsuximide, micafungin, milrinone, oxcarbazepine, rufinamide, voriconazole, and zonisamide.

\subsubsection{Calibration Curve}

Peak heights of posaconazole and ketoconazole obtained in the chromatographic run were used to generate a serum-based calibration curve for posaconazole by using a least squares linear regression of the posaconazole-ketoconazole peak height ratio versus the posaconazole concentration. The calibration curve was used for calculating the concentration of posaconazole in the unknown samples. A calibration curve range of $0.1-10 \mu \mathrm{g} / \mathrm{mL}$ was used to cover the entire range of concentrations in the unknown samples. Plasma is closely related to serum, but the main difference is that it contains clotting factors that help in the clotting of blood. To detect matrix effects on the determination of posaconazole concentration, the plasma calibration curves were compared with the corresponding serum calibration curves.

\subsubsection{Recovery}

Recoveries of posaconazole were evaluated with analyte-free pooled human serum spiked with concentrations varying from 0.3 to $8 \mu \mathrm{g} / \mathrm{mL}$. Ketoconazole was added at the beginning of the extraction process. In one series, the posaconazole standards were spiked before extraction, and in the other series, they were spiked only after the extraction. Samples were analyzed in triplicate. The recovery estimates were based on the comparison of the posaconazole-ketoconazole peak height ratios obtained in both series of samples. Recovery of ketoconazole was evaluated with analyte-free pooled human serum spiked with a concentration of $2 \mu \mathrm{g} / \mathrm{mL}$ before and after the extraction. The recovery estimates were based on the comparison of ketoconazole peak heights obtained in both series of samples. 


\subsubsection{Precision, Reproducibility, and Stability}

Within-run precision was evaluated by the analysis of the QC samples ( $n=5$ at each concentration). To evaluate between-run reproducibility, the QC samples were analyzed on different days $(n=5$ at each concentration). Stabilities of posaconazole and ketoconazole in QC samples were evaluated under a variety of storage and handling conditions: freeze-thaw cycles at room temperature (under chemical/biological hood); bench-top stability (experiments was conducted at room temperature under normal laboratory light for up to $24 \mathrm{~h}$ ); long-term stability (freeze samples for 5 days at $-20^{\circ} \mathrm{C}$ and then thaw for $30 \mathrm{~min}$ at room temperature); the stability of stock solutions of posaconazole and ketoconazole were evaluated; and finally the stability of processed samples sitting on the bench-top for up to $24 \mathrm{~h}$ were tested.

\subsubsection{Cross-Validation}

Cross-validation was performed on 20 patients' samples which were separated into paired sets and stored at $-20^{\circ} \mathrm{C}$ until required. One set of samples was submitted to analysis by LC-MS/MS at the reference laboratory. The second set of patients' samples were analyzed using the current method. To confirm the reliability of this method, paired results from the two different methods were compared.

\section{Results and Discussion}

\subsection{Internal Standard Alternative}

An internal standard is commonly used when many sample preparation steps are required before the sample solution can be injected onto the analytical column. The addition of an internal standard to the sample is known to compensate for any losses during sample preparation and injection onto an analytical instrument. Previously published HPLC/FL methods for the determination of serum posaconazole levels have used itraconazole [32,35] and R051012 [34] as internal standards. While R051012 was not available, itraconazole was first tested in our initial trials. However, the analysis of posaconazole required a lengthy chromatography due to the late elution of itraconazole ( $>14 \mathrm{~min}$ ). After scrutinizing reports for ketoconazole, it was found to exhibit native fluorescent properties at $345-440 \mathrm{~nm}$ with excitation at 240-320 nm [36,37]. As such, ketoconazole was selected and proved to be an excellent alternative which allowed for a shorter chromatography time ( $<8 \mathrm{~min})$.

\subsection{Selectivity}

Figures 1 and 2 are the representative chromatograms obtained after extraction of a blank sample and a patient's sample, respectively. The overall HPLC analysis took $7 \mathrm{~min}$; the retention time of posaconazole was $\sim 6.4 \mathrm{~min}$ and that of the internal standard was $\sim 5.6 \mathrm{~min}$. The selectivity of the FL detection allowed for a good resolution of internal standard and posaconazole without ambiguity in the identification in the analyzed samples. Optimal chromatography conditions had produced satisfactory separations of posaconazole, internal standard, and other unknown peaks. Furthermore, no interference was observed from the analyte-free samples and the Lyphochek ${ }^{\circledR}$ Therapeutic Drug Monitoring Control samples that contained endogenous matrix components, concomitant medications, drug metabolites, decomposition products, and other xenobiotics.

\subsection{Solvent Extraction in a Single Dilution Step}

A single dilution step using organic solvent for simultaneous extraction and protein precipitation was developed in our clinical laboratory in 2001 [38], and it has been used for therapeutic drug monitoring since then. The technique has been proved to be the most rapid and simplest procedure for sample preparation, and is widely accepted in many clinical and analytical laboratories. Quantitative extraction of posaconazole from human plasma or serum has been reported previously by using acetonitrile $[22,26,29,31]$, methanol $[23,31,33]$ or mixtures of both solvents $[19-21,25]$ as the extracting 
reagent in sample preparation. The use of perchloric acid as a precipitating agent had also been previously examined by Zhang et al. [31], and the addition of perchloric acid to methanol extraction proved to be advantageous. Since perchloric acid is extremely hazardous, additional efforts must be made to avoid toxic exposure. For safety purposes, its use has been banned in many clinical laboratories. To find a better alternative, various extraction solvents including acetonitrile, methanol, and mixtures of acetonitrile/methanol $(3 / 1,2 / 2$, and $1 / 3, v / v)$ were evaluated in our preliminary study. No significant differences on the extraction efficiency were observed among these solvents. Methanol alone was selected because its extracts produced the best chromatographic behaviors of both analytes. Methanol extraction produced mean absolute recoveries of $92.4 \% \pm 1.3 \%$ and $91.6 \% \pm 1.3 \%$ for posaconazole and ketoconazole, respectively.

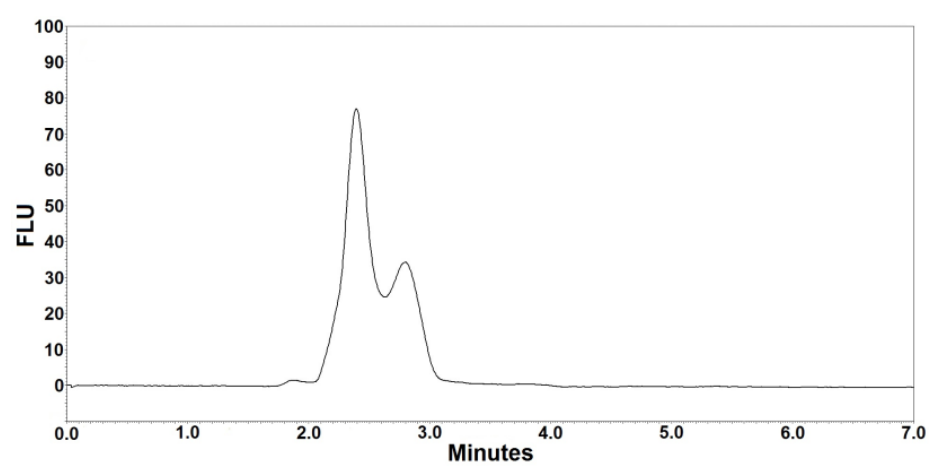

Figure 1. Blank chromatogram after extraction of analyte-free pooled human serum (blank sample).

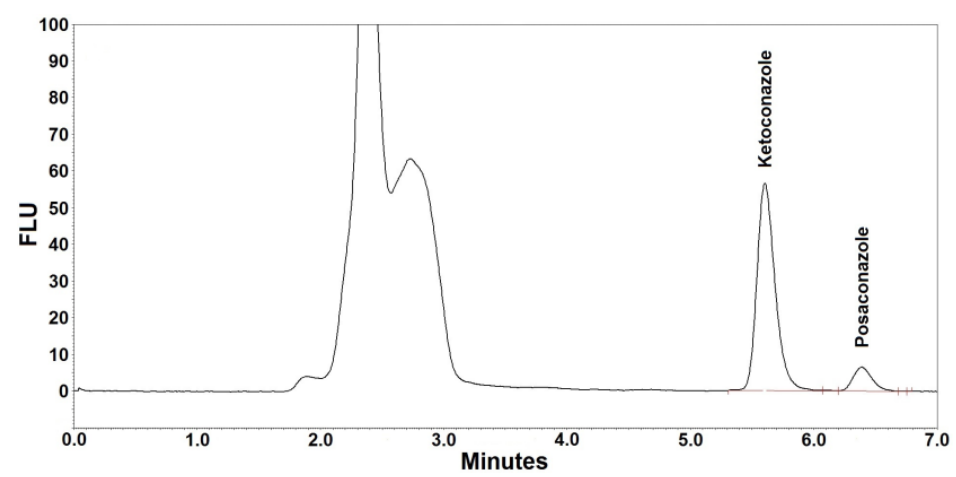

Figure 2. Representative chromatogram (ketoconazole at $\sim 5.6 \mathrm{~min}$, posaconazole at $\sim 6.4 \mathrm{~min}$ ) after extraction of a patient's serum. The posaconazole concentration was $0.98 \mu \mathrm{g} / \mathrm{mL}$.

\subsection{Calibration Curve}

The peak height ratios of posaconazole to ketoconazole were plotted against posaconazole concentration using least squares linear regression. The serum calibration curve was linear over a concentration range of $0.1-10 \mu \mathrm{g} / \mathrm{mL}$ with a correlation coefficient of $\left(r^{2}\right)>0.995$. The slope was $7.876 \pm 0.047$ (mean \pm SD) and the intercept was $0.022 \pm 0.005$ (mean $\pm \mathrm{SD}$ ). The plasma calibration curve had a least squares linear regression equation: $y=7.885 x+0.034$, where $r^{2}=0.996$. Because the serum and plasma calibration curves were parallel, no matrix effects was detected. The linear regression of the serum calibration curve was selected and used to derive the posaconazole concentration in both types of samples. The limit of detection (LOD) was found to be $\sim 0.04 \mu \mathrm{g} / \mathrm{mL}$, which was determined at a signal-to-noise $(\mathrm{S} / \mathrm{N})$ ratio of 3:1, and the limit of quantification (LOQ) was determined to be $0.1 \mu \mathrm{g} / \mathrm{mL}$. The validated linearity was set up to $10 \mu \mathrm{g} / \mathrm{mL}$ for monitoring patients under posaconazole therapy. Table 2 presents the coefficients of variation (CV), which averaged $19 \%$ and $3.9 \%$ for lower limit of quantification (LLOQ) and upper limit of quantification (ULOQ), respectively. The accuracy of 
LLOQ and ULOQ samples ranged from $80 \%$ to $120 \%$ and from $96.5 \%$ to $104.4 \%$, respectively. Based on the Guidance for Industry Bioanalytical Method Validation [39] published by the FDA, the following criteria were met in developing a calibration curve: accuracy within $80 \%-120 \%$ of the target value for the LLOQ and $15 \%$ deviation of standards other than LLOQ from the nominal concentration.

Table 2. Method validation.

\begin{tabular}{ccccc}
\hline Sample & $\begin{array}{c}\text { Sample } \\
\text { Concentration } \\
(\mu \mathrm{g} / \mathrm{mL})\end{array}$ & $\begin{array}{c}\text { Observed } \\
\text { Concentration } \\
(\mu \mathrm{g} / \mathrm{mL})\end{array}$ & $\begin{array}{c}\text { Standard } \\
\text { Deviation }(\mu \mathrm{g} / \mathrm{mL})\end{array}$ & $\mathbf{C V}(\%)$ \\
\hline LLOQ $(n=10)$ & 0.10 & $0.08-0.12$ & 0.02 & 19.0 \\
ULOQ $(n=10)$ & 10.00 & $9.65-10.44$ & 0.39 & 3.9 \\
Patient \#1 $(n=5)$ & 1.23 & $1.15-1.30$ & 0.06 & 4.9 \\
Patient \#2 $(n=5)$ & 0.67 & $0.63-0.72$ & 0.04 & 6.0 \\
Patient \#3 $(n=5)$ & 0.96 & $0.92-1.01$ & 0.05 & 5.2 \\
\hline
\end{tabular}

\subsection{Reproducibility}

Reproducibility of the method was assessed by repeated measurements using the method, including three patient samples (Table 2) and three QCs (Table 3). The reproducibility data for three patient samples containing posaconazole concentrations ranged from 0.63 to $1.30 \mu \mathrm{g} / \mathrm{mL}$ are summarized in Table 2. All CVs for patient samples were $<6 \%$, indicating the reproducibility of the method. The experimental results of the within- and between-run precision tests for QC samples are summarized in Table 3. Within-run precision was between $2.9 \%$ and $5.2 \%$, and between-run precision ranged between $4.0 \%$ and $5.8 \%$. Overall accuracy was between $97.4 \%$ and $105.5 \%$.

Table 3. Method precision and accuracy.

\begin{tabular}{ccccc}
\hline Run & $\begin{array}{c}\text { Nominal } \\
\text { Concentration } \\
(\boldsymbol{\mu g} / \mathbf{m L})\end{array}$ & $\begin{array}{c}\text { Observed } \\
\text { Concentration } \\
(\boldsymbol{\mu g} / \mathbf{m L})\end{array}$ & Recovery (\%) & CV (\%) \\
\hline Within-run $(\boldsymbol{n}=\mathbf{5})$ & 0.300 & 0.303 & 101.1 & 4.5 \\
& 2.00 & 1.95 & 97.4 & 5.2 \\
Between-run $(\boldsymbol{n}=\mathbf{5})$ & 4.00 & 4.16 & 104.1 & 3.6 \\
& 8.00 & 8.04 & 100.6 & 2.9 \\
& 0.300 & 0.293 & 97.7 & 5.3 \\
& 2.00 & 2.11 & 105.5 & 5.8 \\
& 4.00 & 4.09 & 102.3 & 4.1 \\
& 8.00 & 8.17 & 102.2 & 4.0 \\
\hline
\end{tabular}

\subsection{Stability}

Based on the chemistry review on posaconazole conducted by the Center for Drug Evaluation and Research of the FDA, the drug is stable during a period of 24 months stored at $25^{\circ} \mathrm{C}$. Stability-indicating experiments have also been previously conducted by other authors [13-35]. Overall, posaconazole has good stability and degrades only under stress conditions. In the preliminary study, ketoconazole was found to be unstable in an acidic medium, but quite stable in neutral and alkaline media. Therefore, posaconazole and ketoconazole were prepared in a neutral medium and their stability was evaluated under the designed storage and handling conditions as described in the methods section. At $-20{ }^{\circ} \mathrm{C}$, no significant change in concentrations could be observed during $24 \mathrm{~h}$ for both compounds. Stored at room temperature for $24 \mathrm{~h}$, the posaconazole concentration remained constant while the ketoconazole concentration decreased by $5 \%$. However, ketoconazole was stable in prepared samples on the autosampler (at $4{ }^{\circ} \mathrm{C}$ ) of the HPLC system for $24 \mathrm{~h}$. Table 4 presents the results for stability over 5 days at $-20^{\circ} \mathrm{C}$; no significant changes in the posaconazole and ketoconazole concentrations were observed during repeated freeze-thaw cycles. The experiment was carried out using $\mathrm{QC}$ samples that were stored in a freezer $\left(\right.$ at $-20^{\circ} \mathrm{C}$ ) for 5 days. During this period, the freeze-and-thaw cycles were repeated 
three times. The method was proved relevant for the rugged analysis of posaconazole. Our data support the previous claims that posaconazole is stable in all storage and handling conditions between sample collection and analysis (Table 4).

Table 4. Stability data for posaconazole in QC samples.

\begin{tabular}{|c|c|c|c|}
\hline Nominal $(\mu \mathrm{g} / \mathrm{mL})$ & \multicolumn{3}{|c|}{$\begin{array}{c}\text { Measured } \\
\text { Concentration }(\mu \mathrm{g} / \mathrm{mL})\end{array}$} \\
\hline \multicolumn{4}{|c|}{ Freeze-thaw stability ( $n=3$ at each concentration) } \\
\hline & Cycle 1 & Cycle 2 & Cycle 3 \\
\hline 0.300 & 0.296 & 0.302 & 0.304 \\
\hline 2.00 & 2.16 & 1.98 & 2.02 \\
\hline 4.00 & 4.05 & 4.12 & 3.88 \\
\hline 8.00 & 7.85 & 8.07 & 7.96 \\
\hline \multicolumn{4}{|c|}{ Short-term stability at room temperature ( $n=3$ at each concentration) } \\
\hline & & $24 \mathrm{~h}$ & \\
\hline 0.300 & & 0.284 & \\
\hline 2.00 & & 2.15 & \\
\hline 4.00 & & 4.18 & \\
\hline 8.00 & & 8.29 & \\
\hline \multicolumn{4}{|c|}{ Short-term stability at refrigeration $\left(2-8{ }^{\circ} \mathrm{C}, n=3\right.$ at each concentration) } \\
\hline & Day 2 & Day 5 & \\
\hline 0.300 & 0.288 & 0.292 & \\
\hline 2.00 & 2.08 & 2.14 & \\
\hline 4.00 & 4.26 & 4.09 & \\
\hline 8.00 & 7.95 & 8.16 & \\
\hline
\end{tabular}

\subsection{Method Comparison}

When compared with two validated HPLC/UV methods for posaconazole quantification in human serum or plasma samples [29,31], the current method provides a sensitive, cost-effective and time-saving procedure. Cendejas-Bueno et al. [29] used $150 \mu \mathrm{L}$ of serum sample and $50 \mu \mathrm{L}$ of injection volume to obtain an LOQ of $0.125 \mu \mathrm{g} / \mathrm{mL}$ (6.25 $\mathrm{ng}$ on column). Zhang et al. [31] reported a sensitive detection with an LLOQ of $0.05 \mu \mathrm{g} / \mathrm{mL}$ ( $1.5 \mathrm{ng}$ on column) by using $100 \mu \mathrm{L}$ of serum sample and $30 \mu \mathrm{L}$ of injection volume. Based on their results, which showed that posaconazole's retention time was $\sim 6.95 \mathrm{~min}$, the current method could be modified for the determination of posaconazole only with a gradient elution of $8 \mathrm{~min}$ or less. However, the modified procedure still requires an extra $5 \mathrm{~min}$ to allow the initial eluent to equilibrate the column after completing a gradient elution, which is unnecessary for the current method using isocratic elution. The current method took the advantage of sensitive fluorescence detection to achieve an LOQ of $0.1 \mu \mathrm{g} / \mathrm{mL}$ ( $1 \mathrm{ng}$ on column) with a smaller injection volume $(10 \mu \mathrm{L})$ and $100 \mu \mathrm{L}$ of serum sample. Most important, an injection volume of $10 \mu \mathrm{L}$ methanol extract allowed the HPLC system to load 1500 injections without replacing pre-filter columns. According to our experience, the replacement of pre-filter columns was frequently needed after injecting 300-500 samples with an injection volume of $30 \mu \mathrm{L}$ or $50 \mu \mathrm{L}$.

Prior to our current procedure, four HPLC/FL methods have been reported for measuring posaconazole in biological samples. The first method was developed by Muller et al. [32], in which the excitation and emission wavelengths were set at 260 and $365 \mathrm{~nm}$, respectively. Their method required a long chromatography run (>23 $\mathrm{min}$ ) to elute the IS (itraconazole). Sample preparation was tedious and labor-intensive. Although the method was sensitive, it needed $250 \mu \mathrm{L}$ of plasma sample and $50 \mu \mathrm{L}$ of injection volume to achieve an LOQ of $0.05 \mu \mathrm{g} / \mathrm{mL}$ (2.5 $\mathrm{ng}$ on column). Neubauer et al. [33] used different detector settings at 261 and $357 \mathrm{~nm}$ for the excitation and emission, respectively. Although the method needed only $50 \mu \mathrm{L}$ serum, a complicate column-switching technique was used to isolate posaconazole from the serum matrix. This method required a total of 16 min to complete the chromatographic run per injection. Another method was reported by Buckner et al. [34], in which the excitation and emission wavelengths were set at 260 and $350 \mathrm{~nm}$, respectively. Again, the 
method employed tedious sample preparation procedures consisted of liquid-liquid extraction, solvent evaporation and reconstitution prior to analysis. Although a chromatographic run could be completed in $8 \mathrm{~min}$, the R051012 (used as internal standard) was not readily available. The most recent assay was reported by Hens et al. [35], in which the detection was at $385 \mathrm{~nm}$ with excitation at $240 \mathrm{~nm}$, and a gradient run of $19 \mathrm{~min}$ was performed for the analysis. Again, their sample preparation was tedious and labor-intensive; sample volume was $1000 \mu \mathrm{L}$. In comparison, the current method used a simpler sample preparation, a smaller sample volume $(100 \mu \mathrm{L})$, and a shorter chromatographic run time ( $<8 \mathrm{~min}$ ). The optimized fluorescence detection was at $380 \mathrm{~nm}$ with excitation at $245 \mathrm{~nm}$. Figure 3 shows the fluorescence intensities of posaconazole and ketoconazole at different settings. The current method offers the most sensitive detection.

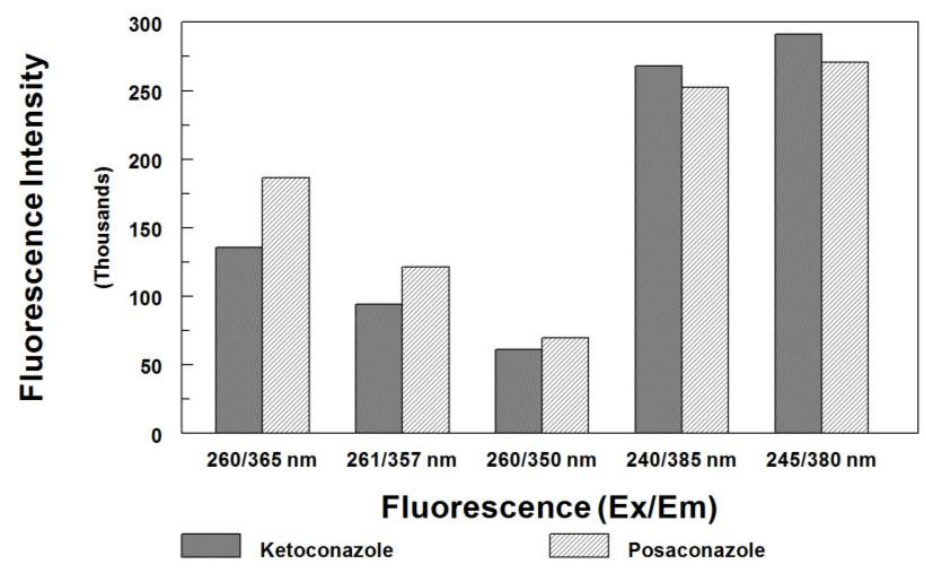

Figure 3. Comparison of fluorescence intensity for posaconazole $(7.5 \mu \mathrm{g} / \mathrm{mL})$ and ketoconazole $(2 \mu \mathrm{g} / \mathrm{mL})$ at different settings used in previously published methods and the current method (mean measured peak height, $n=3$ ).

\subsection{Cross-Validation}

Cross-validation of the current method was examined by measuring the concentrations of posaconazole ranged from 0.1 to $1.4 \mu \mathrm{g} / \mathrm{mL}$ in 20 de-identified patient samples. The results obtained by this method were compared well with results from the reference method (Figure 4). The correlation between the two methods was good; the linear regression statistics indicated an $r^{2}$ value of 0.982 $(p<0.0001)$. The linear regression equation for the correlation was $y=0.986 x-0.017$ with a standard error value of 0.027 ; where $y$ denotes the current method and $x$ denotes the reference method.

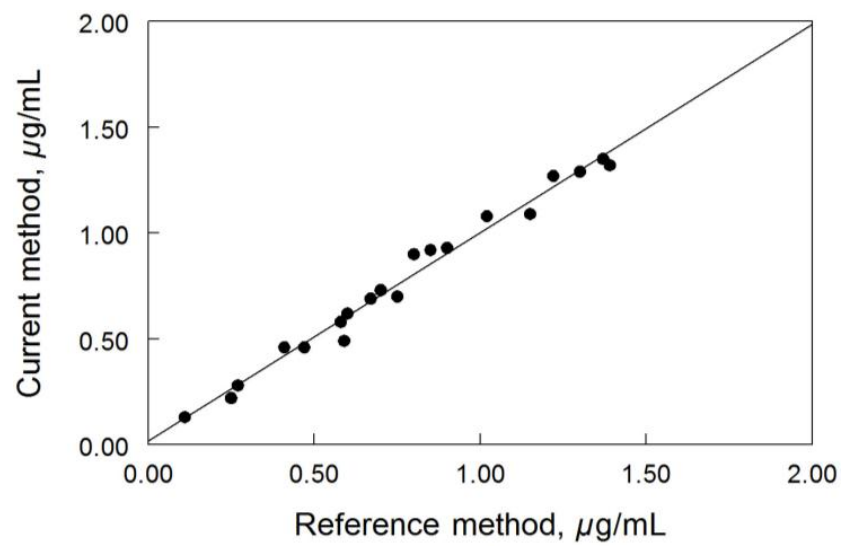

Figure 4. Cross-validation of posaconazole method $(n=20)$. 


\section{Conclusions}

A simple, rapid, and accurate method for the measurement of posaconazole in human plasma/serum has been developed. The current method uses an efficient procedure consisting of a single dilution step, protein precipitation and centrifugation which avoids the use of more complex liquid-liquid extraction or solid-phase extraction procedures and substantially decreases the sample preparation time. The method meets the requirements of high sample throughput in clinical practice. The method has potential cost savings lying in the use of a single dilution step process and a quick chromatographic run to be completed within $8 \mathrm{~min}$. This method can also be readily adopted by clinical and analytical laboratories to support the monitoring of posaconazole concentrations in plasma/serum, to optimize the efficacy of posaconazole therapy and minimize adverse effects.

Acknowledgments: The author wishes to thank the Department of Pathology and Laboratory Medicine, Cincinnati Children's Hospital Medical Center for the internal funding for the work performed in this study.

Conflicts of Interest: The author declares no conflict of interest.

\section{References}

1. Schiller, D.; Fung, H. Posaconazole: An extended-spectrum triazole antifungal agent. Clin. Ther. 2007, 29, 1862-1886. [CrossRef] [PubMed]

2. Rachwalski, E.; Wieczorkiewicz, J.; Scheetz, M. Posaconazole: An oral triazole with an extended spectrum of activity. Ann. Pharmacother. 2008, 42, 1429-1438. [CrossRef] [PubMed]

3. Li, X.; Brown, N.; Chau, A.; López-Ribot, J.; Ruesga, M.; Quindos, G.; Mendrick, C.; Hare, R.; Loebenberg, D.; DiDomenico, B.; et al. Changes in susceptibility to posaconazole in clinical isolates of Candida albicans. J. Antimicrob. Chemother. 2004, 53, 74-80. [CrossRef] [PubMed]

4. Walsh, T.; Raad, I.; Patterson, T.; Chandrasekar, P.; Donowitz, G.; Graybill, R.; Greene, R.; Hachem, R.; Hadley, S.; Herbrecht, R.; et al. Treatment of Invasive Aspergillosis with Posaconazole in Patients Who Are Refractory to or Intolerant of Conventional Therapy: An Externally Controlled Trial. Clin. Infect. Dis. 2007, 44, 2-12. [CrossRef] [PubMed]

5. Torres, H.; Hachem, R.; Chemaly, R.; Kontoyiannis, D.; Raad, I. Posaconazole: A broad-spectrum triazole antifungal. Lancet Infect. Dis. 2005, 5, 775-785. [CrossRef]

6. Lipp, H. Clinical pharmacodynamics and pharmacokinetics of the antifungal extended-spectrum triazole posaconazole: An overview. Br. J. Clin. Pharmacol. 2010, 70, 471-480. [CrossRef] [PubMed]

7. Li, Y.; Theuretzbacher, U.; Clancy, C.; Nguyen, M.; Derendorf, H. Pharmacokinetic/pharmacodynamic profile of posaconazole. Clin. Pharmacokinet. 2010, 49, 379-396. [CrossRef] [PubMed]

8. Kraft, W.; Chang, P.; van Iersel, M.; Waskin, H.; Krishna, G.; Kersemaekers, W. Posaconazole tablet pharmacokinetics: Lack of effect of concomitant medications altering gastric $\mathrm{pH}$ and gastric motility in healthy subjects. Antimicrob. Agents Chemother. 2014, 58, 4020-4025. [CrossRef] [PubMed]

9. Maertens, J.; Cornely, O.; Ullmann, A.; Heinz, W.; Krishna, G.; Patino, H.; Caceres, M.; Kartsonis, N.; Waskin, H.; Robertson, M. Phase 1B study of the pharmacokinetics and safety of posaconazole intravenous solution in patients at risk for invasive fungal disease. Antimicrob. Agents Chemother. 2014, 58, 3610-3617. [CrossRef] [PubMed]

10. McKeage, K. Posaconazole: A review of the gastro-resistant tablet and intravenous solution in invasive fungal infections. Drugs 2015, 75, 397-406. [CrossRef] [PubMed]

11. Kersemaekers, W.; van Iersel, T.; Nassander, U.; O'Mara, E.; Waskin, H.; Caceres, M.; van Iersel, M. Pharmacokinetics and safety study of posaconazole intravenous solution administered peripherally to healthy subjects. Antimicrob. Agents Chemother. 2015, 59, 1246-1251. [CrossRef] [PubMed]

12. Luke, D.; Tomaszewski, K.; Damle, B.; Schlamm, H. Review of the basic and clinical pharmacology of sulfobutylether-beta-cyclodextrin (SBECD). J. Pharm. Sci. 2010, 99, 3291-3301. [CrossRef] [PubMed]

13. Dolton, M.; Brüggemann, R.; Burger, D.; McLachlan, A. Understanding variability in posaconazole exposure using an integrated population pharmacokinetic analysis. Antimicrob. Agents Chemother. 2014, 58, 6879-6885. [CrossRef] [PubMed] 
14. Dolton, M.; Ray, J.; Marriott, D.; McLachlan, A. Posaconazole exposure-response relationship: Evaluating the utility of therapeutic drug monitoring. Antimicrob. Agents Chemother. 2012, 56, 2806-2813. [CrossRef] [PubMed]

15. Dolton, M.; Ray, J.; Chen, S.; Ng, K.; Pont, L.; McLachlan, A. Multicenter study of posaconazole therapeutic drug monitoring: Exposure-response relationship and factors affecting concentration. Antimicrob. Agents Chemother. 2012, 56, 5503-5510. [CrossRef] [PubMed]

16. Seyedmousavi, S.; Mouton, J.; Verweij, P.; Brüggemann, R. Therapeutic drug monitoring of voriconazole and posaconazole for invasive aspergillosis. Expert Rev. Anti-Infect. Ther. 2013, 11, 931-941. [CrossRef] [PubMed]

17. Ashbee, H.; Barnes, R.; Johnson, E.; Richardson, M.; Gorton, R.; Hope, W. Therapeutic drug monitoring (TDM) of antifungal agents: Guidelines from the British Society for Medical Mycology. J. Antimicrob. Chemother. 2013, 69, 1162-1176. [CrossRef] [PubMed]

18. Cunliffe, J.; Noren, C.; Hayes, R.; Clement, R.; Shen, J. A high-throughput LC-MS/MS method for the quantitation of posaconazole in human plasma: Implementing fused core silica liquid chromatography. J. Pharm. Biomed. Anal. 2009, 50, 46-52. [CrossRef] [PubMed]

19. Vogeser, M.; Rieger, C.; Ostermann, H.; Spöhrer, U. A routine method for the quantitation of the novel antimycotic drug posaconazole in plasma using liquid chromatography-tandem mass spectrometry. Clin. Chem. Lab. Med. 2009, 47, 579-584. [CrossRef] [PubMed]

20. Rochat, B.; Pascual, A.; Pesse, B.; Lamoth, F.; Sanglard, D.; Decosterd, L.; Bille, J.; Marchetti, O. Ultra-performance liquid chromatography mass spectrometry and sensitive bioassay methods for quantitation of posaconazole plasma concentrations after oral dosing. Antimicrob. Agents Chemother. 2010, 54, 5074-5081. [CrossRef] [PubMed]

21. Alffenaar, J.; Wessels, A.; van Hateren, K.; Greijdanus, B.; Kosterink, J.; Uges, D. Method for therapeutic drug monitoring of azol antifungal drugs in human serum using LC/MS/MS. J. Chromatogr. B Anal. Technol. Biomed. Life Sci. 2010, 878, 39-44. [CrossRef] [PubMed]

22. Baietto, L.; D'Avolio, A.; Ventimiglia, G.; De Rosa, F.; Siccardi, M.; Simiele, M.; Sciandra, M.; Di Perri, G. Development, validation, and routine application of a high-performance liquid chromatography method coupled with a single mass detector for quantification of itraconazole, voriconazole, and posaconazole in human plasma. Antimicrob. Agents Chemother. 2010, 54, 3408-3413. [CrossRef] [PubMed]

23. Beste, K.; Burkhardt, O.; Kaever, V. Rapid HPLC-MS/MS method for simultaneous quantitation of four routinely administered triazole antifungals in human plasma. Clin. Chim. Acta 2012, 413, 240-245. [CrossRef] [PubMed]

24. Baietto, L.; D’Avolio, A.; Marra, C.; Simiele, M.; Cusato, J.; Pace, S.; Ariaudo, A.; De Rosa, F.; Di Perri, G. Development and validation of a new method to simultaneously quantify triazoles in plasma spotted on dry sample spot devices and analysed by HPLC-MS. J. Antimicrob. Chemother. 2012, 67, 2645-2649. [CrossRef] [PubMed]

25. Chae, H.; Cho, S.; Yu, H.; Cha, K.; Lee, S.; Kim, M.; Kim, Y.; Kim, Y.J.; Kim, H.J.; Lee, D.G. Determination of posaconazole concentration with LC-MS/MS in adult patients with hematologic malignancy. Clin. Chim. Acta 2015, 450, 220-226. [CrossRef] [PubMed]

26. Chhun, S.; Rey, E.; Tran, A.; Lortholary, O.; Pons, G.; Jullien, V. Simultaneous quantification of voriconazole and posaconazole in human plasma by high-performance liquid chromatography with ultra-violet detection. J. Chromatogr. B Anal. Technol. Biomed. Life Sci. 2007, 852, 223-228. [CrossRef] [PubMed]

27. Storzinger, D.; Swoboda, S.; Lichtenstern, C.; Müller, C.; Weigand, M.; Hoppe-Tichy, T. Development and validation of a high-performance liquid chromatography assay for posaconazole utilizing solid-phase extraction. Clin. Chem. Lab. Med. 2008, 46, 1747-1751. [CrossRef] [PubMed]

28. Kahle, K.; Langmann, P.; Schirmer, D.; Lenker, U.; Keller, D.; Helle, A.; Klinker, H.; Heinz, W. Simultaneous determination of voriconazole and posaconazole concentrations in human plasma by high-performance liquid chromatography. Antimicrob. Agents Chemother. 2009, 53, 3140-3142. [CrossRef] [PubMed]

29. Cendejas-Bueno, E.; Forastiero, A.; Rodriguez-Tudela, J.; Cuenca-Estrella, M.; Gomez-Lopez, A. HPLC/UV or bioassay: Two valid methods for posaconazole quantification in human serum samples. Clin. Microbiol. Infect. 2012, 18, 1229-1235. [CrossRef] [PubMed] 
30. Wissen, C.; Burger, D.; Verweij, P.; Aarnoutse, R.; Brüggemann, R. Simultaneous determination of the azoles voriconazole, posaconazole, isavuconazole, itraconazole and its metabolite hydroxyl-itraconazole in human plasma by reversed phase ultra-performance liquid chromatography with ultraviolet detection. J. Chromatogr. B Anal. Technol. Biomed. Life Sci. 2012, 887-888, 79-84. [CrossRef] [PubMed]

31. Zhang, M.; Moore, G.; Barclay, M.; Begga, E. A simple high-performance liquid chromatography method for simultaneous determination of three triazole antifungals in human plasma. Antimicrob. Agents Chemother. 2013, 57, 484-489. [CrossRef] [PubMed]

32. Muller, C.; Arndt, M.; Queckenberg, C.; Cornely, O.; Theisohn, M. HPLC analysis of the antifungal agent posaconazole in patients with haematological diseases. Mycoses 2006, 49 (Suppl. 1), 17-22. [CrossRef] [PubMed]

33. Neubauer, W.; Konig, A.; Bolek, R.; Trittler, R.; Engelhardt, M.; Jung, M.; Kümmerer, K. Determination of the antifungal agent posaconazole in human serum by HPLC with parallel column-switching technique. J. Chromatogr. B Anal. Technol. Biomed. Life Sci. 2009, 877, 2493-2498. [CrossRef] [PubMed]

34. Buckner, S.; Ceesay, M.; Pagliuca, A.; Morgan, P.; Flanagan, R. Measurement of posaconazole, itraconazole, and hydroxyitraconazole in plasma/serum by high-performance liquid chromatography with fluorescence detection. Ther. Drug Monit. 2011, 33, 735-741. [CrossRef] [PubMed]

35. Hens, B.; Corsetti, M.; Brouwers, J.; Augustijns, P. Gastrointestinal and systemic monitoring of posaconazole in humans after fasted and fed state administration of a solid dispersion. J. Pharm. Sci. 2016, 105, 2904-2912. [CrossRef] [PubMed]

36. Remmel, R.; Amoh, K.; Abdel-Monem, M. The disposition and pharmacokinetics of ketoconazole in the rat. Drug Metab. Dispos. 1987, 15, 735-739. [PubMed]

37. Khashaba, P.; El-Shabouri, S.; Emara, K.; Mohamed, A. Analysis of some antifungal drugs by spectrophotometric and spectrofluorimetric methods in different pharmaceutical dosage forms. J. Pharm. Biomed. Anal. 2000, 22, 363-376. [CrossRef]

38. Tang, P.; Miles, M.; DeGrauw, A.; Hershey, A.; Pesce, A. HPLC analysis of reduced and oxidized coenzyme Q10 in human plasma. Clin. Chem. 2001, 47, 256-265. [PubMed]

39. U.S. Department of Health and Human Services; Food and Drug Administration; Center for Drug Evaluation and Research. Guidance for Industry: Bioanalytical Method Validation. 2001.

(C) 2017 by the author. Licensee MDPI, Basel, Switzerland. This article is an open access article distributed under the terms and conditions of the Creative Commons Attribution (CC BY) license (http:/ / creativecommons.org/licenses/by/4.0/). 